UDC 338.48:352.071

DOI: 10.15673/fie.v11i3.1466

\author{
Dobrianska N. \\ Doctor of Economics, Professor \\ Department of Administrative Management and \\ Market Problems \\ Odessa National Polytechnic University \\ Prospekt Shevchenko, 1, Odessa, Ukraine, 65000 \\ E-mail: semen-198@te.net.ua \\ ORCID ID: 0000-0002-0826-8840
}

\author{
Nikoliuk 0. \\ Doctor of Economics, Associate Professor \\ Department of Management and Logistics \\ Odessa National Academy of Food Technologies \\ Kanatna str., 112, Odesa, Ukraine, 65039 \\ E-mail: alenavn11@gmail.com \\ ORCID ID: 0000-0002-1665-0361
}

\author{
Lebedieva V. \\ Doctor of Economics, Professor \\ Department of Administrative Management and Market Problems \\ Odessa National Polytechnic University \\ Prospekt Shevchenko, 1, Odessa, Ukraine, 65000 \\ E-mail: veralebedeva@ukr.net \\ ORCID ID: 0000-0001-8127-4860
}

\title{
ORGANIZATIONAL AND ECONOMIC MEASURES OF TOURISM DEVELOPMENT ON THE EXAMPLE OF THE AVANGARD UNITED TERRITORIAL COMMUNITY OF ODESSA REGION
}

The article has analyzed the dynamics of the creation of the united territorial communities (UTC) in the Odessa region and Ukraine, the state and development trends of the tourism resources market in the Odessa region were studied, and the main problems of tourism development were identified, the SWOT matrix - the analysis of the tourism activities of the united territorial community was built, strengths and weaknesses, opportunities and threats of further social and economic development of the society were identified, the main competitive advantages of the territorial community were identified, the dynamics of the development of the tourism infrastructure of the united territorial community were investigated, a one-day tourist route for the united territorial community - "I love you Avangard" was worked out, strategic directions for the development of the tourism business were identified, a financial plan for the development of the united territorial community of the future for the implementation of strategic areas of tourism was proposed.

Key words: tourism, tourism resources, united territorial community, strategic directions.

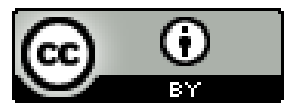

This work is licensed under a Creative Commons Attribution 4.0 International License http://creativecommons.org/licenses/by/4.0/

Statement of the problem and its connection with important scientific and practical tasks. According to the Law of Ukraine "On Tourism", "the state proclaims tourism one of the priority directions of economic and cultural development and creates conditions for tourist activity" [1].

The tourism industry of the Odessa region in its current state is not completely satisfactory for the development of a powerful tourism industry in this region [2].

The tourism industry cannot develop without high-quality promotion of the community's tourism opportunities. Since 2015 , the process of the voluntary integration of the united territorial communities in Ukraine has begun.

In developing a development strategy for territorial communities, considerable attention should be paid to the development of tourism, which is one of the priority areas of the state.

The analysis of the latest publications on the problem. Theoretical and methodological approaches to the development of tourism are described in the scientific works of domestic scientists, among them: O. Liubitseva [3,4], E. Pankova [4], V. Stafiichuk [4], M. Malska [5], N. Antoniuk [5], N. Hanych [5]. The main aspects of the development of the united territorial communities are reflected in the works of O.A. Batalova [6], E.I. Borodin [8], N.V. Vasylyeva [7], N.T. Honcharuk [8], N.M. Hrinchuk [7], T.M. Derun [7], V.S. Kuybida [7], A.P. Oliinyk [6], A.P. Pavlyuk [6], S.M. Seryohin [8], A.F. Tkachuk [7], Yu.P. Sharov [8] and others.

However, a number of important problems of forming a stable and effective development of the united territorial communities have not yet been properly resolved. Further research requires dealing with questions related to the development of an effective mechanism of economic relations between tourism enterprises, tour operators, travel agents and state and local authorities. The solution of the above mentioned problematic issues requires an integrated approach to the use of tourism as a strategic direction aimed at increasing the activity of the united territorial communities [9]. 
Forming of the aims of the research. The purpose of this study is to examine the state and trends of the voluntary creation of united territorial communities, identify strategic directions for the development of the tourism business of communities and improve them.

Giving an account of the main results and their substantiation. The beginning of the XXI century is marked by the heyday of domestic tourism, as more than half of the tourists $(58 \%)$ preferred to rest in the Odessa region, which indicates the interest of tourists to their native land. But since 2016, this trend has changed and foreign tourism began to prevail, in which more than $60 \%$ of the citizens of Odessa region vacationed abroad. One of the reasons for Ukrainians visiting foreign resorts is the insufficient development of interesting and unique routes in Ukraine [10].

The development of tourism affects the stabilization of the economic development of a certain territory, the level of employment, provides demographic stability and improves the socio - economic development of the territorial community.

A territorial community is residents united by permanent residence within a village, settlement, city, which are independent administrative-territorial units, or a voluntary association of residents of several villages, settlements with a single administrative center, village council [11].

The dynamics of creation of United Territorial Communities (UTC) in Odessa region and Ukraine as a whole is presented in Fig. 1.

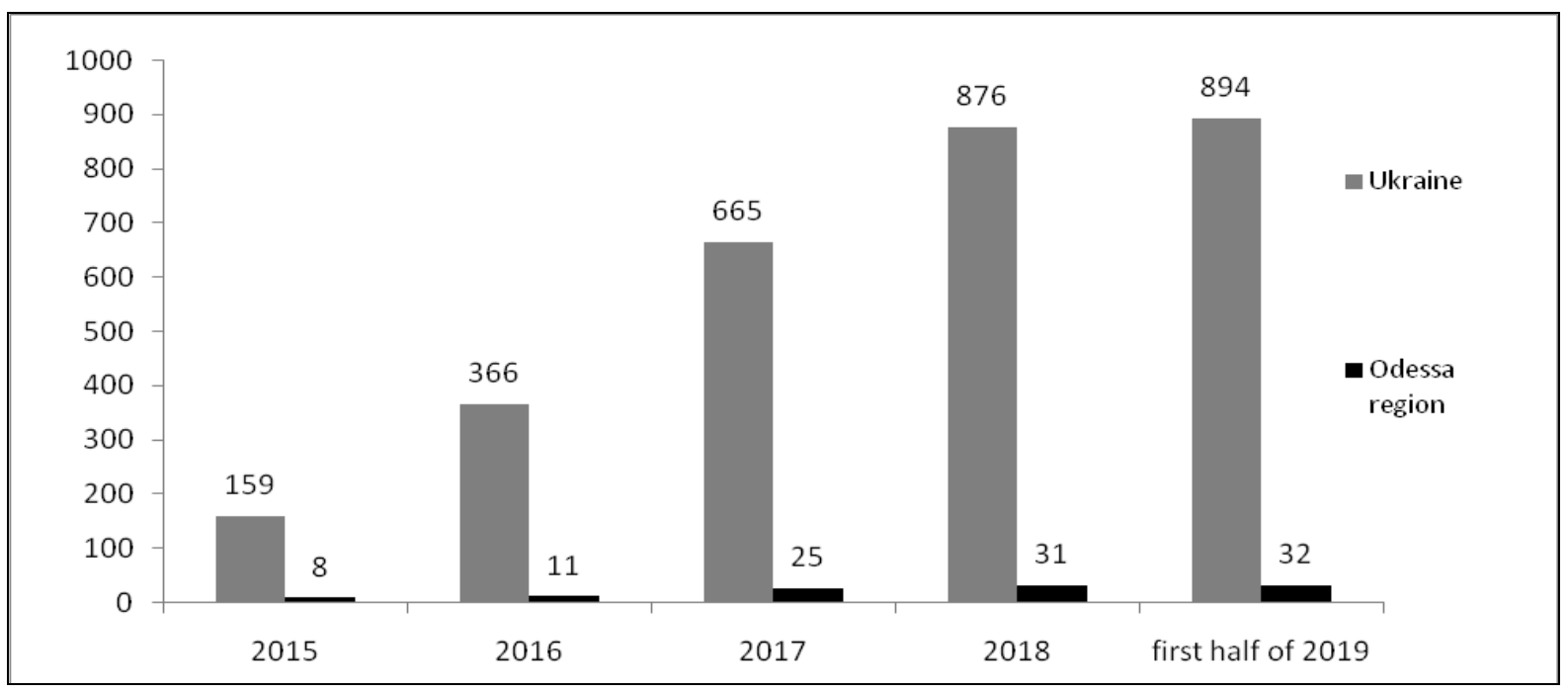

Fig. 1. Dynamics of creation of united territorial communities in Odessa region and Ukraine * *constructed by authors using sources $[12,13,14]$

Since mid-2015, the process of creating united territorial communities has begun and continues to the present. In 2015, 159 UTC were created in Ukraine, including in the Odessa region - only 8 . The growth rates of the created UTC in Ukraine exceed their growth rates in the Odessa region. So, as of the first half of 2019 , compared with 2015 in Ukraine, the number of created UTC increased by 5.6 times, while in the Odessa region only in 4 times. $30.1 \%$ of the total area and $14 \%$ of the total number of inhabitants of the Odessa region is the territory of 32 created UTC

The sizes of the created UTC varies in their sizes in terms of population, territory, budget, etc. The territory of the Avangard UTC of the Ovidiopol district is 34.5 $\mathrm{km}^{2}$ and is the smallest in terms of the area of the created UTC in the Odessa region.

The development of a territorial community affects the functioning of certain sectors of local selfgovernment, including tourism. Therefore, we offer the Avangard UTC to develop the tourism industry, as it is an example of a modern European village and the youngest settlement in the Ovidiopol district, which has natural, historical, cultural and other resources, as well as a close proximity to the tourist center of Odessa. Using the SWOT analysis, we identify the strengths and weaknesses, the opportunities and threats of further social and economic development of the Avangard UTC (table 1).

\section{SWOT - analysis of tourist activities Avangard UTC *}

\begin{tabular}{|l|l|l|}
\hline \multicolumn{1}{|c|}{$\begin{array}{l}\text { Opportunities (O) } \\
\text { Opening EU markets for products }(\mathbf{T}) \\
\text { produced in society. } \\
\text { Increasing popularity of tourism } \\
\text { among the population of Ukraine, } \\
\text { the development of domestic tour- } \\
\text { ism. }\end{array}$} & $\begin{array}{l}\text { The unstable situation in the coun- } \\
\text { try. } \\
\text { rency, the continuation of inflatio- } \\
\text { nary processes. } \\
\text { Limited financial resources for the } \\
\text { development of society. } \\
\text { Demographic and social crisis. }\end{array}$ \\
\hline
\end{tabular}


Continue of table1

\begin{tabular}{|c|c|c|}
\hline & $\begin{array}{l}\text { Opportunities (O) } \\
\text { Construction of a new international } \\
\text { transport corridor, increasing the flow } \\
\text { of tourists from the Vanguard by open- } \\
\text { ing a border crossing point. Adoption of } \\
\text { the Law of Ukraine "On Transfer of } \\
\text { Powers of Land Disposal Beyond Set- } \\
\text { tlements to UTCs" will become a po- } \\
\text { werful factor in attracting tourism de- } \\
\text { velopment investments to the commu- } \\
\text { nity. } \\
\text { Continuation of the European integra- } \\
\text { tion processes will contribute to the } \\
\text { increase of investors' interest in UTC } \\
\text { for tourism development. } \\
\text { Start of international technical assis- } \\
\text { tance projects in Ukraine that will sup- } \\
\text { port the united communities. } \\
\text { Budget support for the development of } \\
\text { tourism in the united communities. }\end{array}$ & $\begin{array}{l}\quad \text { Threats }(\mathbf{T}) \\
\text { Weak positioning of the region- } \\
\text { al tourism product. } \\
\text { Environmental crises. } \\
\text { Monopolization of markets. } \\
\text { Population aging. }\end{array}$ \\
\hline $\begin{array}{l}\text { Strengths (S) } \\
\text { Proximity to the regional center of } \\
\text { Odessa and the customs border cross- } \\
\text { ing points with Moldova. } \\
\text { Availability of free land resources for } \\
\text { public development and investment } \\
\text { attraction. } \\
\text { Developed sports infrastructure. } \\
\text { UTC Vanguard is located in the center } \\
\text { of transit tourist routes. } \\
\text { The presence in the company of enter- } \\
\text { prises with foreign investment that } \\
\text { effectively operate and provide an } \\
\text { example to other investors. } \\
\text { The presence of actively working pub- } \\
\text { lic organizations that successfully im- } \\
\text { plement tourism development projects. }\end{array}$ & $\begin{array}{l}\text { SxO } \\
\text { - strategy of concentrated growth } \\
\text { (access to new tourist markets is possi- } \\
\text { ble) } \\
- \text { a strategy for integrated growth, } \\
\text { namely vertical integration (implemen- } \\
\text { tation of public-private partnerships). }\end{array}$ & $\begin{array}{l}\text { SxT } \\
\text { - concentrated growth strategy. } \\
\text { In this case, it is advisable to } \\
\text { begin to provide additional } \\
\text { tourism services. Such a step } \\
\text { will increase competitiveness, } \\
\text { and, accordingly, the number of } \\
\text { tourists will increase; } \\
\text { - a strategy for integrated } \\
\text { growth, namely horizontal } \\
\text { integration. Association of } \\
\text { tourism enterprises - } \\
\text { competitors in the association. } \\
\text { This will improve the tourist } \\
\text { base, increase the capacity of } \\
\text { UTC. }\end{array}$ \\
\hline $\begin{array}{l}\text { Weaknesses (W) } \\
\text { Lack of innovation in tourism. } \\
\text { The need for reconstruction of build- } \\
\text { ings and monuments of historical sig- } \\
\text { nificance. } \\
\text { Low level of organization of leisure } \\
\text { activities in the community. } \\
\text { Low level of development of tourist } \\
\text { infrastructure, services in public cater- } \\
\text { ing establishments. } \\
\text { Lack of internal routing } \\
\text { Lack of tour operators. } \\
\text { Not enough places to rest. }\end{array}$ & $\begin{array}{l}\text { WxO } \\
\text { - concentrated growth strategy. Since } \\
\text { there are more weaknesses in Avangard } \\
\text { UTC than strengths, the most effective } \\
\text { are actions to strengthen positions in } \\
\text { the tourism market (the creation of a } \\
\text { positive sustainable image in Odessa } \\
\text { and the region, an increase in the } \\
\text { number of tourists, etc. should be } \\
\text { attributed); } \\
\text { - A cost-cutting strategy is also } \\
\text { advisable, since the level of income in } \\
\text { Avangard UTC is low. Estimated costs } \\
\text { will require large financial investments, } \\
\text { so now it is necessary to lower the cost } \\
\text { bar. For example, the search for tour } \\
\text { operators with more affordable prices } \\
\text { for tourists. }\end{array}$ & $\begin{array}{l}\text { WxT } \\
\text { - a diversified growth strategy, } \\
\text { namely horizontal } \\
\text { diversification. UTC Avangard, } \\
\text { it is necessary to establish work } \\
\text { on the provision of new } \\
\text { additional tourist services; } \\
\text { - a strategy of centered } \\
\text { diversification. UTC Vanguard } \\
\text { may begin to provide a new } \\
\text { tourism service based on } \\
\text { existing ones. Such actions will } \\
\text { lead to increased revenues, } \\
\text { competitiveness will increase. }\end{array}$ \\
\hline
\end{tabular}

* created by the authors based on their own observations

So, Avangard UTC has great prospects for the development of the tourism industry, connected with favorable geographical location (proximity to the main tourist center of Ukraine - Odessa), good transport links and sufficient natural and cultural resources of the society, which will allow to receive additional funds and thereby to replenish state and local budgets annually, and as a consequence this will have a potentially positive impact 
on related fields.

The main competitive advantage of Avangard UTC is the presence in its territory of enterprises of national importance, the main budget-forming taxpayers of UTC and creation of a large part of high-paying jobs, a high level of security of agricultural lands and recreational resources creates opportunities for tourism development.

Inland tourism can form the basis for the further development of the industry and the attraction of the new capital to the avant-garde UTC. It is also important to enter new international markets. It is necessary to cooperate with representations of other countries in order to attract more inbound tourists and to maintain clear positions in the international tourist arena. Another way to accomplish this task is to participate in tourist exhibitions, create portals, develop an effective information and marketing strategy.

A one-day all-season tourist route to the Avangard UTC - "I love you Avangard" with a visit to "Promrynok $7 \mathrm{~km}$ " has been developed, to get acquainted with local historical and modern buildings, to visit the Park of 60th Anniversary of Victori (it preserves the only collection of military aircrafts in the Odessa region), the temple complex of St. Martyr Victor and St. great martyr Irina, attending a local winemaker, visit to a souvenir shop on Dobryansky, Square. All tourists receive a wonderful book by S. Khrustovsky "I love you Avangard". The cost of the tour "I love you Avangard" for 1 person will be $450 \mathrm{UAH}$ (the price includes the price of the book).

To date, the tour will be in demand: because of a low price, maximum workload and comfortable conditions. Avangard UTC provides all the conditions for informing tourists.

To develop tourism in the Avangard UTC, we offer a number of events:

1. It is necessary to organize and create a camping station on the rowing canal Avangard UTC, which requires a layout of the territory, arrangement of moorings, landscape design, infrastructure arrangement of the adjacent territory, information support for potential tourists.
2. Organization of art spaces; repair of abandoned hangars and rowing greenhouses, purchase of necessary equipment (complex stalls, lighting equipment, sound equipment), attracting organizers of festivals, exhibitions and concerts, attracting potential customers with the help of extensive information.

3. Creation of children's entertainment facilities.

4. Introduction of a tourist guest card - this is the so-called smart card that allows residents of the Odessa region and tourists to visit attractions without buying individual tickets.

5. Creating a scene for the development of event tourism: national festivals and holidays; theatrical shows; film and theater festivals; gastronomic festivals; festivals and flower shows; music festivals and music competitions.

6. Promoting the tourism potential of UTC Avangard: it is necessary to develop and implement an effective communication strategy, which will include the functioning of the community's tourism portal, the issuance of printed advertising materials, the presentation of the community's features at tourism exhibitions and thematic events.

7. Development and operation of a tourist Internet resource where all the information that a potential tourist will need about Avangard UTC will be accumulated: hotels and catering, historical sights, photos and information to them, navigation on thematic routes, proposals for green tourism or outdoor activities, poster of large-scale cultural events in the society.

8. Carrying out activities to promote the tourism potential of the Avangard United Territorial Community souvenirs, etc. The implementation of the tasks of the strategic directions of tourism development of the Avangard United Territorial Community involves the fulfillment of many tasks at the same time by various structures of the executive committee of the united territorial community with the participation of many partners, which poses the issue of rational management of a complex process with very limited funds for development. Indicative financial plan of 2019-2021 is presented in table 2 .

Table 2

The financial plan of the Avangard UTC of the future for the implementation of the strategic areas of tourism, thousand $\mathrm{UAH}^{*}$

\begin{tabular}{|c|c|c|c|c|}
\hline Name of the event & 2019 & 2020 & 2021 & $\begin{array}{l}\text { The total amount } \\
\text { for the project }\end{array}$ \\
\hline $\begin{array}{l}\text { Organization of events to ensure tourism } \\
\text { facilities and tourism business with qual- } \\
\text { ified personnel }\end{array}$ & 10 & 10 & 10 & 30 \\
\hline $\begin{array}{l}\text { Development of documentation neces- } \\
\text { sary for the development of tourism in- } \\
\text { frastructure }\end{array}$ & 10 & 15 & 10 & 35 \\
\hline $\begin{array}{l}\text { Creating a tourist route to the Avangard } \\
\text { UTC }\end{array}$ & 10 & 10 & 10 & 30 \\
\hline $\begin{array}{l}\text { Organization and creation of a camping - } \\
\text { station on the Rowing canal }\end{array}$ & 100 & 150 & 200 & 450 \\
\hline Organization of art spaces & 70 & 150 & 200 & 420 \\
\hline $\begin{array}{l}\text { Creation of children's entertainment } \\
\text { facilities }\end{array}$ & 70 & 100 & 150 & 320 \\
\hline Introduction of a tourist guest card & 30 & 30 & 30 & 90 \\
\hline
\end{tabular}


Continue of table 2

\begin{tabular}{|l|c|c|c|c|}
\hline \multicolumn{1}{|c|}{ Name of the event } & 2019 & 2020 & 2021 & $\begin{array}{c}\text { The total amount } \\
\text { for the project }\end{array}$ \\
\hline $\begin{array}{l}\text { Creating a stage for the development of } \\
\text { event tourism }\end{array}$ & 150 & 200 & 200 & 550 \\
\hline $\begin{array}{l}\text { Development and operation of a tourist } \\
\text { Internet resource }\end{array}$ & 30 & 50 & 50 & 130 \\
\hline $\begin{array}{l}\text { Carrying out activities to promote the } \\
\text { tourism potential of UTC }\end{array}$ & 25 & 75 & 50 & 150 \\
\hline Total & 505 & 790 & 910 & 2205 \\
\hline
\end{tabular}

*authors' own calculations

So, based on the information from Table 2, the following assumptions that are important for the implementation of the strategic development plan for the Avangard UTC can be distinguished: the success of the declared actions, the effectiveness of responding to external challenges, and increasing the ability of local governments to implement local development programs as part of the strategy.

Other assumptions are the continued provision of a state subvention for the development of UTC infrastructure, transparent and competitive access to the funds of the State Regional Development Fund, as well as the availability of other financing provided by the specific projects for their implementation.

All interested parties should be involved in the implementation of the strategic plan - public organizations, international technical assistance programs, government agencies, private investors.

The development of tourism is of great importance, both for tourists and for residents of the Avangard united territorial community. It provides an active vacation, acquaintance with the color of the area, its traditions and habits, and for the Avangard united territorial community it is an opportunity to receive additional cash receipts, replenish the budget of local authorities, and improve the infrastructure of the territory. At the present stage of the development of the society, the effectiveness of the united territorial community depends on the development of tourism, in the future it will create new jobs, reduce the internal migration movement of the population, especially for young people, and ensure the social and economic revival of the territory.

Prospects for further research are the development of an integrated mechanism for measuring the effectiveness of public-private partnerships in the field of tourism on the principles of project management, which allow us to develop and implement measures in the direction of strategic development of the united territorial communities [15].

Conclusions and prospects of the further investigations. There are certain problems in the development of the tourism industry. The main one is that today there is the inefficient and irrational use of appropriate resources, underfunding from the state, and the current level of development of the tourism industry does not match the existing potential, the lack of quality advertising and indepth information about services and so on.

The analysis also makes it possible to identify the main problems and obstacles that impede investment to the Avangard United Territorial Community.

Strategic directions may include the development of a system of low-cost hotel-hostels in the Avangard UTC, information support from specialists in the field of local history, geography, geology, history, the integration of science and business through the cooperation between entrepreneurs and scientists, the development of information infrastructure, information exchange between regions via the Internet, organization of exhibitions, fairs, popularization of the historical and cultural heritage of the community through the mass media.

The tourist attractiveness of the Avangard UTC area requires the intensification of promotional and organizational activities, the organization of documentation related to cultural sites, the creation of local tourist routes and the production of unique souvenir products.

Attracting of demanding European tourists is associated with the labeling of bilingual tourist signposts of tourist routes and facilities and the creation of a bilingual promotional online resource.

An additional synergistic effect will result in the placement of information on the Avangard UTC tourist product on the sites of well-known travel agencies and their inclusion in the pan-European tourist routes.

To ensure a high level of tourist services in the community it is necessary to conduct systematic work with all entities of tourism industry.

It is necessary to ensure the opportunity to learn positive experiences of other communities, carrying out an active dialogue and cooperation between structures of the tourist destination of the community.

Certification and inventory of tourist attractions will allow you to collect and unify all available information about tourist attractions. The generated data can be used to develop numerous thematic routes by the community.

\section{References}

1. Pro turyzm: Zakon Ukrainy № 324/95-VR za stanom na 04.11.2018 r. (2018). Retrieved July 10, 2019, from https://zakon.rada.gov.ua/laws/show/324/95-\%Do\%B2\%D1\%80

2. Vorobiova, O. A. (2011). Problemy ta perspektyvy rozvytku rekreatsiino - turystychnoi diialnosti v pivdennykh raionakh Odeskoi oblasti. Ekonomichni Innovatsii, (44), 46-56. 
3. Liubitseva, O. O. (2006). Rynok turystychnykh posluh. Kyiv: Alterpres. Alterpres.

4. Liubitseva, O. O., Pankova, Ye. V., \& Stafiichuk, V. I. (2007). Turystychni resursy Ukrainy. Kyiv: Znannia.

5. Malska, M. P., Antoniuk, N. V., \& Hanych, N. M. (2008). Mizhnarodnyi turyzm i sfera posluh. Kyiv:

6. Pavliuk, A. P., Oliinyk, A. P., \& Batalov, O. A. (2016). Terytorialna hromada yak bazova lanka administratyvno - terytorialnoho ustroiu Ukrainy: problemy ta perspektyvy reformuvannia. Kyiv: NISD.

7. Vasylieva, N. V. (2017). Mistsevyi biudzhet i finansove zabezpechennia ob 'iednanoi terytorialnoi hromady. Kyiv.

8. Serohin, S. M. (2016). Upravlinnia stratehichnym rozvytkom ob’iednanykh terytorialnykh hromad: innovatsiini pidkhody ta instrumenty. Dp.: DRIDU NADU.

9. Dobrianska, N. A., \& Popovych, V. V. (2018). «Zelenyi» turyzm yak stratehichnyi napriam sotsialnoekonomichnoho rozvytku rehioniv Ukrainy. Ekonomika: Realii Chasu, (3 (37), 20-28. doi: 10.5281/zenodo.1326369

10. Dobrianska, N. A., Stoianova - Koval, S. S., \& Nikoliuk, O. V. (2018). Realii sohodennia ta perspektyvy rozvytku turystychnoho biznesu Odeskoi oblasti. Ekonomika Kharchovoi Promyslovosti, 10(1), 9-15. doi: 10.15673/fie.v10i1.861

11. Pro mistseve samovriaduvannia v Ukraini: Zakon Ukrainy vid 21.05.1997 №280/97-VR za stanom na 01.05.2019r. (2019). Retrieved July 10, 2019, from http://zakon2.rada.gov.ua/laws/show/280/97-вр.

12. Formuvannia ob'iednannia terytorialnykh hromad: stan, problemni pytannia ta shliakhy yikh vyrishennia. Analitychna zapyska. Retrieved July 12, 2019, from http://www.niss.gov.ua/content/articles/files/terutor_gromad86ead.pdf.

13. Zvit pro zdiisnennia Odeskoiu oblasnoiu derzhavnoiu administratsiieiu pokladenykh na nei povnovazhen ta stan rozvytku terytorii u 2018 rotsi. Retrieved July 11, 2019, from https://oda.odessa.gov.ua/statics/pages/files/5c541a5409eb5.pdf.

14. Monitorynh protsesu detsentralizatsii vlady ta reformuvannia mistsevoho samovriaduvannia. Retrieved July 10, 2019, from https://storage.decentralization.gov.ua/uploads/library/file/359/10.01.2019.pdf.

15. Lebedeva, V., Dobrianska, N., \& Gromova, L. (2018). Public-private partnership as the leadership composition of the development of industrial production. In Atlantis Press. 2nd International Conference on Social, economic, and academic leadership (ICSEAL 2018). Advances in Social Science, Education and Humanities Research (Vol. 217, pp. 78-86). doi: 10.2991/icseal-18.2018.12

Received 20 July 2019

Approved 4 August 2019 Available in Internet 16.10.2019

Добрянская H.A.

доктор экономических наук, профессор кафедра административного менеджмента и проблем рынка

Одесский национальный политехнический университет

проспект Шевченко, 1, г. Одесса, Украина, 65000

E-mail: semen-198@te.net.ua

ORCID ID: 0000-0002-0826-8840
Николюк E.B.

доктор экономических наук, доцент кафедра менеджмента и логистики Одесская национальная академия пищевых технологий

ул. Канатная, 112, г. Одесса, Украина, 65039

E-mail: alenavn11@gmail.com

ORCID ID: 0000-0002-1665-0361

\section{Лебедева В.В.}

доктор экономических наук, профессор кафедра административного менеджмента и проблем рынка Одесский национальный политехнический университет проспект Шевченко, 1, г. Одесса, Украина, 65000

E-mail: veralebedeva@ukr.net ORCID ID: 0000-0001-8127-4860

\section{ОРГАНИЗАЦИОННО-ЭКОНОМИЧЕСКИЕ МЕРЫ РАЗВИТИЯ ТУРИЗМА НА ПРИМЕРЕ АВАНГАРДСКОЙ ОБЪЕДИНЕННОЙ ТЕРРИТОРИАЛЬНОЙ ОБЩИНЫ ОДЕССКОЙ ОБЛАСТИ}

В статье проанализирована динамика создания объединенных территориальных общин в Одесской области и Украины. Размеры созданных ОТО различаются в своих размерах по численности населения, территории, бюджетом и др. Площадь территорий Авангардской ОТО Овидиопольского района составляет 34,5 км ${ }^{2}$ и является самой маленькой по площади созданных ОТО в Одесской области. 
Предлагаем Авангардской ОТО развивать туристическую отрасль, так как она является примером современного европейского поселка и самым молодым населенным пунктом Овидиопольского района, в которой есть природные, исторические, культурные и другие ресурсы.

Изучено состояние и тенденции развития рынка туристических ресурсов в Одесской области, выявлены основные проблемы развития туризма. Внутренний туризм может стать основой для дальнейшего развития отрасли и привлечения нового капитала в Авангардскую ОТО. Также важен выход на новые международные рынки. Нужно сотрудничать с представительствами других государств с целью привлечения большего количества въездных туристов и содержание четких позиций на международной туристической арене. Еще один способ выполнения данной задачи - участие в туристических выставках, создание порталов, разработка эффективной информационно - маркетинговой стратегии.

Построено матрицу SWOT - анализа туристической деятельности объединенной территориальной общины, определены сильные и слабые стороны и возможности и угрозы дальнейшего социального и экономического развития общества, выявлены основные конкурентные преимущества территориальной общины, исследована динамика развития инфраструктуры сферы туризма объединенной территориальной общины, разработан однодневный туристический маршрут для объединенной территориальной общины - «Я люблю тебя Авангард», определены стратегические направления развития туристического бизнеса, предложено финансовый план развития объединенной территориальной общины на перспективу по реализации стратегических направлений туризма.

Стратегическими направлениями может стать развитие системы недорогих отелей-хостелов в Авангардской ОТО, информационная поддержка со стороны специалистов в области краеведения, географии, геологии, истории, интеграция науки и бизнеса через сотрудничество предпринимателей и ученых, развитие информационной инфраструктуры, информационный обмен между регионами через Интернет, организация выставок, ярмарок, популяризация историко-культурного наследия общины через средства массовой инфрормации.

Необходимо обеспечить возможность изучения положительного опыта других общин, активный диалог и сотрудничество между структурами туристического направления общины.

Ключевые слова: туризм, туристические ресурсы, объединенная территориальная община, стратегические направления.

Добрянська Н.А.

доктор економічних наук, профресор кафредра адміністративного менеджменту та проблем ринку

Одеський національний політехнічний університет, проспект Шевченка, 1, м. Одеса, Україна, 65000

E-mail: semen-198@te.net.ua

ORCID ID: 0000-0002-0826-8840
Ніколюк О.В.

доктор економічних наук, доцент кафедра менеджменту та логістики Одеська національна академія харчових технологій,

вул. Канатна, 112, м. Одеса, Україна, 65039

E-mail: alenavn11@gmail.com

ORCID ID: 0000-0002-1665-0361

Лебедєва В.В.

доктор економічних наук, профессор

кафедра адміністративного менеджменту та проблем ринку

Одеський національний політехнічний університет,

проспект Шевченка, 1, м. Одеса, Україна, 65000

E-mail: veralebedeva@ukr.net

ORCID ID: 0000-0001-8127-4860

\section{ОРГАНІЗАЦІЙНО-ЕКОНОМІЧНІ ЗАХОДИ РОЗВИТКУ ТУРИЗМУ НА ПРИКЛАДІ АВАНГАРДІВСЬКОЇ ОБ'ЄДНАНОЇ ТЕРИТОРІАЛЬНОЇ ГРОМАДИ ОДЕСЬКОЇ ОБЛАСТІ}

У статті проаналізовано динаміку створення об'єднаних територіальних громад (ОТГ) в Одеській області та Україні. Розміри створених об'єднаних територіальних громад різняться в своїх розмірах за чисельністю населення, території, бюджетом та ін. Площа територій Авангардівської об'єднаної територіальної громади Овідіопольського району становить 34,5 км$^{2}$ i $є$ найменшою за площею створених ОТГ в Одеській області. 
Запропоновано Авангардівській ОТГ розвивати туристичну галузь, так як вона є прикладом сучасного європейського селища і наймолодшим населеним пунктом Овідіопольського району, в якій $є$ природні, історичні, культурні та інші ресурси.

Вивчено стан і тенденції розвитку ринку туристичних ресурсів в Одеській області, виявлено основні проблеми розвитку туризму. Внутрішній туризм може стати основою для подальшого розвитку галузі та залучення капіталу в Авангардівську ОТГ. Також важливим є вихід на нові міжнародні ринки. Потрібно співпрацювати з представництвами інших держав з метою залучення більшої кількості в'їзних туристів та утримання чітких позицій на міжнародній туристичній арені. Ще один спосіб виконання даного завдання - участь у туристичних виставках, створення порталів, розробка ефективної інформаційно - маркетингової стратегії.

Побудовано матрицю SWOT - аналізу туристичної діяльності об'єднаної територіальної громади, визначені сильні і слабкі сторони та можливості і загрози подальшого соціального та економічного розвитку суспільства, виявлено основні конкурентні переваги територіальної громади, досліджено динаміку розвитку інфраструктури сфери туризму об'єднаної територіальної громади, розроблений одноденний туристичний маршрут для об'єднаної територіальної громади - «Я люблю тебе Авангард», визначені стратегічні напрямки розвитку туристичного бізнесу, запропоновано фінансовий план розвитку об'єднаної територіальної громади на перспективу по реалізації стратегічних напрямків туризму.

Стратегічними напрямками може стати розвиток системи недорогих готелів-хостелів в Авангардівській ОТГ, інформаційна підтримка з боку фахівців в галузі краєзнавства, географії, геології, історії, інтеграція науки і бізнесу через співпрацю підприємців та вчених, розвиток інформаційної інфраструктури, інформаційний обмін між регіонами через Інтернет, організація виставок, ярмарків, популяризація історико-культурної спадщини громади через засоби масової інформації.

Необхідно забезпечити можливість вивчення позитивного досвіду інших громад, активний діалог і співробітництво між структурами туристичного напрямку громади.

Перспективами подальших досліджень є розробка інтегрованого механізму застосування вимірювання ефективності державно-приватного партнерства в галузі туризму на принципах управління проектами, які дозволять розробити і здійснити заходи у напрямку стратегічного розвитку об'єднаних територіальних громад напрямки.

Ключові слова: туризм, туристичні ресурси, об'єднана територіальна громада, стратегічні

\section{Література}

1. Про туризм: Закон України № 324/95-ВР за станом на 04.11.2018 р. / Верховна Рада України. URL: https://zakon.rada.gov.ua/laws/show/324/95-\%D0\%B2\%D1\%80 (дата звернення 10.07.2019)

2. Воробйова О.А. Проблеми та перспективи розвитку рекреаційно - туристичної діяльності в південних районах Одеської області // Економічні інновації. 2011. Вип. 44. С. 46-56.

3. Любіцева О.О. Ринок туристичних послуг. К.: Альтерпрес, 2006. 436 с.

4. Любіцева О.О., Панкова С.В., Стафійчук В.І. Туристичні ресурси України. К.: Альтерпрес, 2007. 369

c.

5. Мальська М.П., Антонюк Н.В., Ганич Н.М. Міжнародний туризм і сфера послуг. К.: Знання, 2008. $661 \mathrm{c}$.

6. Павлюк А.П., Олійник А.П., Баталов О.А. Територіальна громада як базова ланка адміністративно територіального устрою України: проблеми та перспективи реформування. К.: НІСД, 2016. 61 с.

7. Місцевий бюджет і фінансове забезпечення об’єднаної територіальної громади: навч. посіб. / Васильєва Н. В.та ін. К., 2017. 119 с.

8. Управління стратегічним розвитком об’єднаних територіальних громад: інноваційні підходи та інструменти: монографія. / Серьогін С. М. та ін. Дп.: ДРІДУ НАДУ, 2016. 276 с.

9. Добрянська Н.А., Попович В.В. «Зелений» туризм як стратегічний напрям соціально-економічного розвитку регіонів України // Економіка: реалії часу. Науковий журнал. 2018. № 3 (37). С. 20-28. doi: 10.5281/zenodo.1326369.

10. Добрянська Н.А., Стоянова - Коваль С.С., Ніколюк О.В. Реалії сьогодення та перспективи розвитку туристичного бізнесу Одеської області // Економіка харчової промисловості. 2018. Т. 10, вип. 1. С. 9-15. doi.org/10.15673/fie.v10i1.861

11. Про місцеве самоврядування в Україні: Закон України від 21.05.1997 №280/97-ВР за станом на 01.05.2019p. / ВР України. URL: http://zakon2.rada.gov.ua/laws/show/280/97-\%D0\%B2\%D1\%80 (дата звернення 10.07.2019)

12. Формування об’єднання територіальних громад: стан, проблемні питання та шляхи їх вирішення. Аналітична записка. URL: http://www.niss.gov.ua/content/articles/files/terutor_gromad-86ead.pdf (дата звернення 12.07.2019) 
13. Звіт про здійснення Одеською обласною державною адміністрацією покладених на неї повноважень та стан розвитку території у 2018 році. URL: https://oda.odessa.gov.ua/statics/pages/files/5c541a5409eb5.pdf (дата звернення 11.07.2019)

14. Моніторинг процесу децентралізації влади та реформування місцевого самоврядування. URL: https://storage.decentralization.gov.ua/uploads/library/file/359/10.01.2019.pdf (дата звернення 10.07.2019)

15. Lebedeva V., Dobrianska N., Gromova L. (2018). Public-private partnership as the leadership composition of the development of industrial production. Atlantis Press. 2nd International Conference on Social, economic, and academic leadership (ICSEAL 2018). Advances in Social Science, Education and Humanities Research, volume 217. p. 78-86. doi.org/10.2991/icseal-18.2018.12

Стаття надійшла 20.07.2019

Стаття прийнята до друку 3.08.2019

Доступно в мережі Internet 16.10.2019

Цитування згідно ДСТУ 8302:2015

Dobrianska N., Nikoliuk O., Lebedieva V. Organizational and economic measures of tourism development on the example of the Avangard United Territorial Community of Odessa region // Food Industry Economics. 2019. Vol.11, Issue 3. P. 88-96. doi: 10.15673/fie.v11i3.1466

Cite as APA style citation

Dobrianska, N., Nikoliuk, O., \& Lebedieva, V. (2019). Organizational and economic measures of tourism development on the example of the Avangard United Territorial Community of Odessa region. Food Industry Economics, 11(3), 88-96. doi: 10.15673/fie.v11i3.1466 